\title{
Aneurysmal Bone Cyst of the Cervical Spine: Clinical Case Report
}

ISSN: 2576-8875

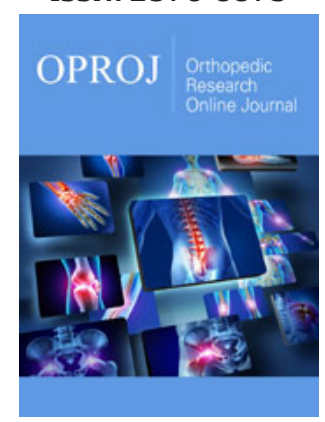

*Corresponding author: Luiz Cláudio Lacerda Rodrigues, Head of the Orthopedic Discipline Santa Marcelina School Of Medicine, Brazil

Submission: 留 May 29, 2020

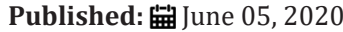

Volume 7 - Issue 2

How to cite this article: Luiz Claudio Lacerda Rodrigues, Fernanda Andrea Minutti Navarro, Rodrigo Yuiti Nakao, Daniela De Moraes Brasil. Aneurysmal Bone Cyst of the Cervical Spine: Clinical Case Report. Ortho Res Online J. 7(2). OPROJ. 000657. 2020.

DOI: 10.31031/OPROJ.2020.07.000657

Copyright@: Luiz Claudio Lacerda Rodrigues, This article is distributed under the terms of the Creative Commons Attribution 4.0 International License, which permits unrestricted use and redistribution provided that the original author and source are credited.

\author{
Luiz Claudio Lacerda Rodrigues ${ }^{1 *}$, Fernanda Andrea Minutti Navarro' ${ }^{2}$, Rodrigo \\ Yuiti Nakao ${ }^{2}$ and Daniela De Moraes Brasil ${ }^{3}$ \\ ${ }^{1}$ Head of the Orthopedic Discipline Santa Marcelina School Of Medicine, Brazil \\ ${ }^{2}$ Department of Orthopedics and Traumatology, Hospital Santa Marcelina, Brazil \\ ${ }^{3}$ Medical Student, Santa Marcelina School of Medicine, Brazil
}

\begin{abstract}
Aneurysmal bone cyst has a benign, hypervascularized, aggressive behavior due to the progressive, destructive and compressive growth of adjacent structures. Its symptomatology is variable, being able to cause from pain to the patient to neurological complaints, preferentially affecting long bones and vertebrae [1-5].

We report a case of aneurysmal bone cyst of the cervical spine affecting an adult man, presenting limitations of cervical movements and neurological alterations during the clinical follow-up. The diagnosis was established through radiography and computed tomography; puncture biopsy was performed to rule out differential diagnoses. The patient was submitted to surgical procedure for resecting the tumor and the affected vertebrae, in addition to stabilizing the cervical spine. In this case, infusion of local intra operative corticoid was performed as a method of association to reduce the risk of relapse. The patient progressed satisfactorily, showing a significant improvement in the movement of the cervical spine and in the neurological picture, demonstrating efficacy in the Magerl surgical technique for stabilizing the cervical spine, and in the transoral approach for resecting the tumor of cervical involvement. We discuss the treatment of choice in relation to all the currently existing ones, and the evolution of this patient.
\end{abstract}

Keywords: Benign tumor; Bone cyst; Cervical spine; Surgical technique; Orthopedic care

List of Abbreviations: SAE: Selective Arterial Embolization; Et. al.: And others; CT: Computed Tomography

Introduction

Aneurysmal bone cysts represent $1 \%$ of all the benign bone tumors affecting children, adolescents and young adults, and may affect any bone of the body, predominantly long bones and vertebral bodies [6-10]. They are formed by blood spaces and trabecular bone tissue, presenting varied and discusses able behaviors towards treatments [11-14]. The causes are still unknown, and may be traumatic, vascular or even genetic [15-18].

Those are generally destructive and expansive tumors, causing sensitive neurological and motor alterations when they compress nerve roots, besides weakening the bone tissue and favoring fractures in low-energy events [19-23]. The diagnosis is made through image exams, such as X-ray photographs and magnetic resonance, and biopsies are performed with needles for differential diagnoses [24-28]. The treatments are still varied, the selective arterial embolization (SAE) being currently the first-line option. They also present good response to immune modulators and, in some cases, radiotherapy is necessary [24]. When located in the spine, for there being structural destructions, open surgery must be performed by resection and/or curettage, with posterior grafting and instrumentation when necessary [29-33]. Surgical removal keeps being the most successful treatment, preventing spinal deformities, besides controlling the area to prevent possible relapses.

\section{Case Report}

Patient ECS, male, aged 36,Caucasian, single, worksite painter, born in Bahia, living in São Paulo, checked in the outpatient clinic of the health service of Hospital Santa Marcelina in Itaquera-SP, with a 4-month complaint of mechanical neck pain, with progressive worsening, with no history of trauma. 
At the physical examination, the patient presented absence of lesions and phlogistic signs of the underlying skin, painful palpation of the cervical region, besides a moderate reduction in its extension of movement, deriving from intense pain in movements of flexion, extension and lateral bending to the left and to the right, besides rotation to both sides of the cervical spine. He also globally kept level 5 strength scales, besides a satisfactory neurological test as regards nerve roots $\mathrm{C} 5, \mathrm{C} 6, \mathrm{C} 7, \mathrm{C} 8$, and $\mathrm{T} 1$.

According to the patient's symptoms and physical examination, $\mathrm{X}$-ray photographs of the cervical and thoracic spine were requested, providing altered findings. Multilocular, radiolucent, cystic mass level CII/CIII was visualized, surrounded by septation of bone tissue with diverticular-shapedinternal projection son the cyst wall, besides the cortical discontinuity of the CII vertebral body.

The treatment proposal was divided into three stages. In the first, the patient under-went biopsy by cervical spine puncture at the CII vertebra level by transpolar percutaneous incision aided by fluoroscopy, which confirmed the diagnosis. A month after the material collection, the patient was submitted to arthrodesis of the cervical spine, when the occipital region at CIV level was exposed to perform the stabilization of the CI-CII segment, following the Magerl technique described in the literature. Atricortical bone graft from the iliac crest was placed in the posterior portion of the cervical spine, followed by needle pass via transoral anterior for collecting material for the biopsy, associated to the infusion of corticoid in the CII body.

Five months after the second intervention, the patient presented global neurological deficit with signs of myelopathy (loss of balance and fine movements). A mandibular osteo to my by the transoral approach was performed, when the cervical vertebra lesion was resected, besides making an incision in the chin region, with para cervical extension for Odontoid body resection and of CII/ CIII vertebral discs. Still at this stage, there was the very patient's fibula grafting, and cervical plate with screws in the CIII body, with posterior mandibular repositioning and rigid fixation of symphysis.

Computer Tomography was performed eight months after the last surgical intervention, evidencing the correct positioning of stabilization for both systems, besides the absence of radiological signs of relapse.

Five years after the surgical interventions, the patient keeps the same job with cross bite complaint and periodontal pain. Panoramic $\mathrm{X}$-ray photographs were taken, the image suggesting generalized horizontal bone loss, yet without alterations in the plate and screws positioning in CII/CIII. Therefore, the patient has under gone dental follow-up (Figure 1-6).
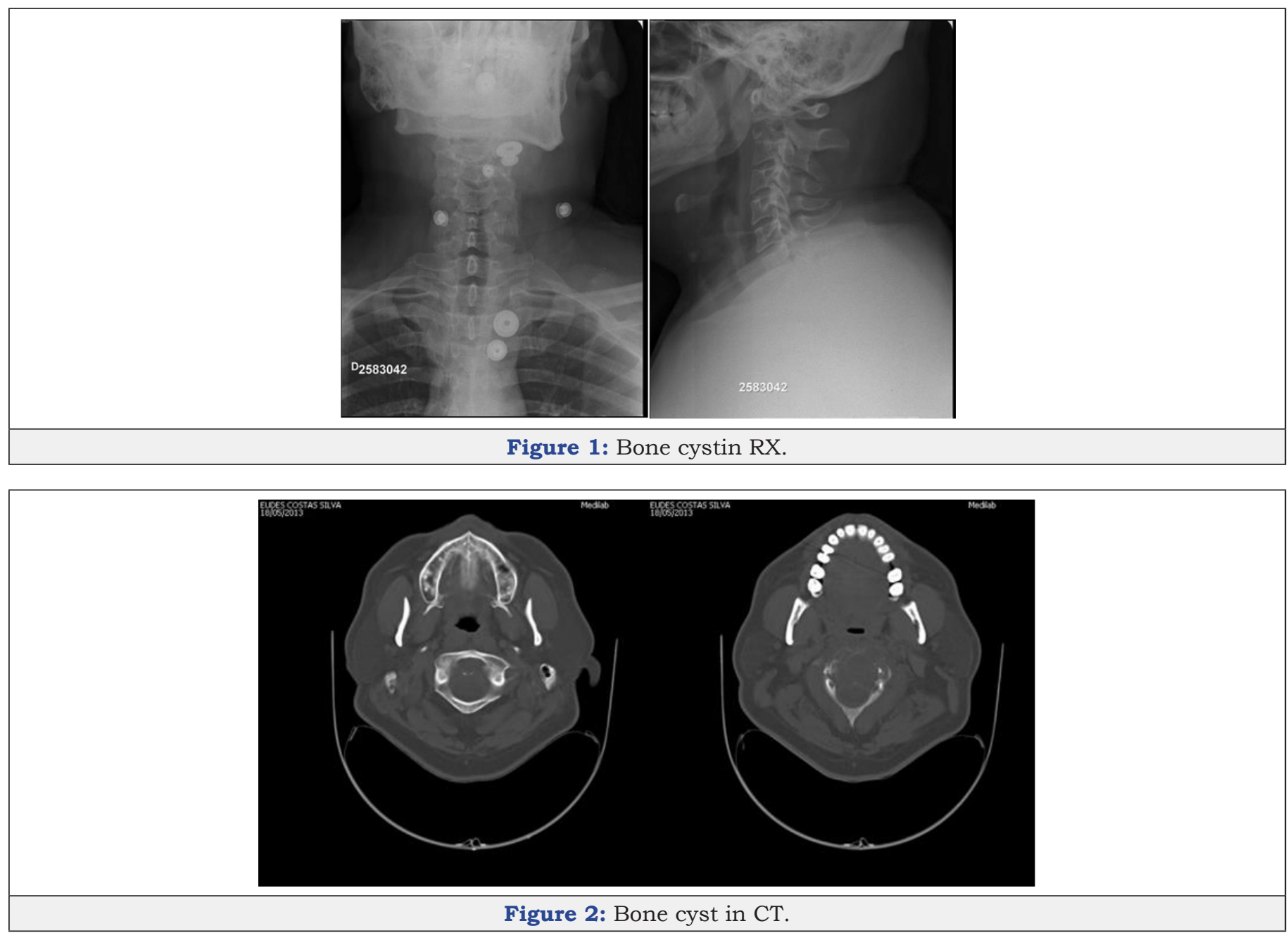

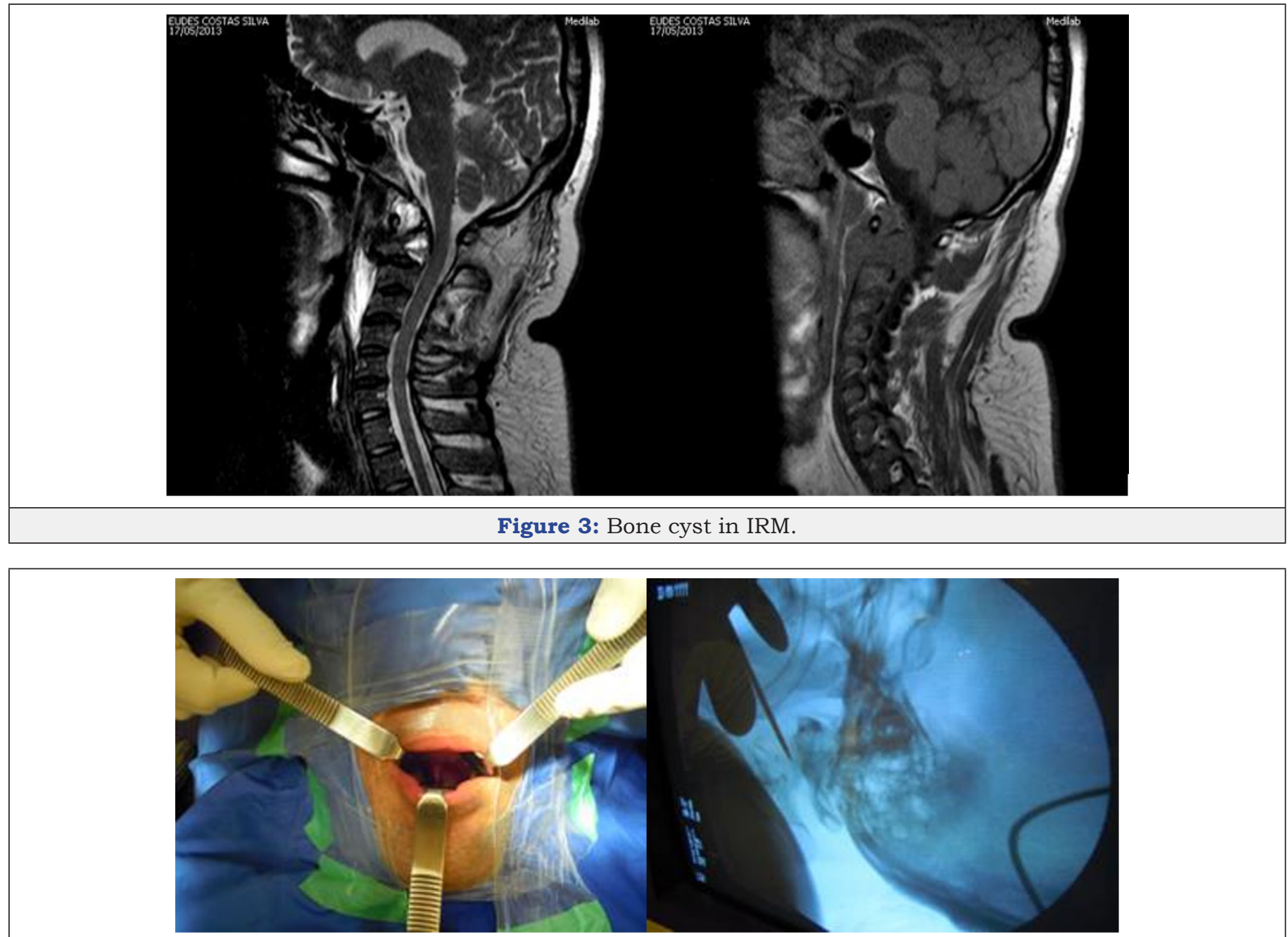

Figure 4: Biopsy.

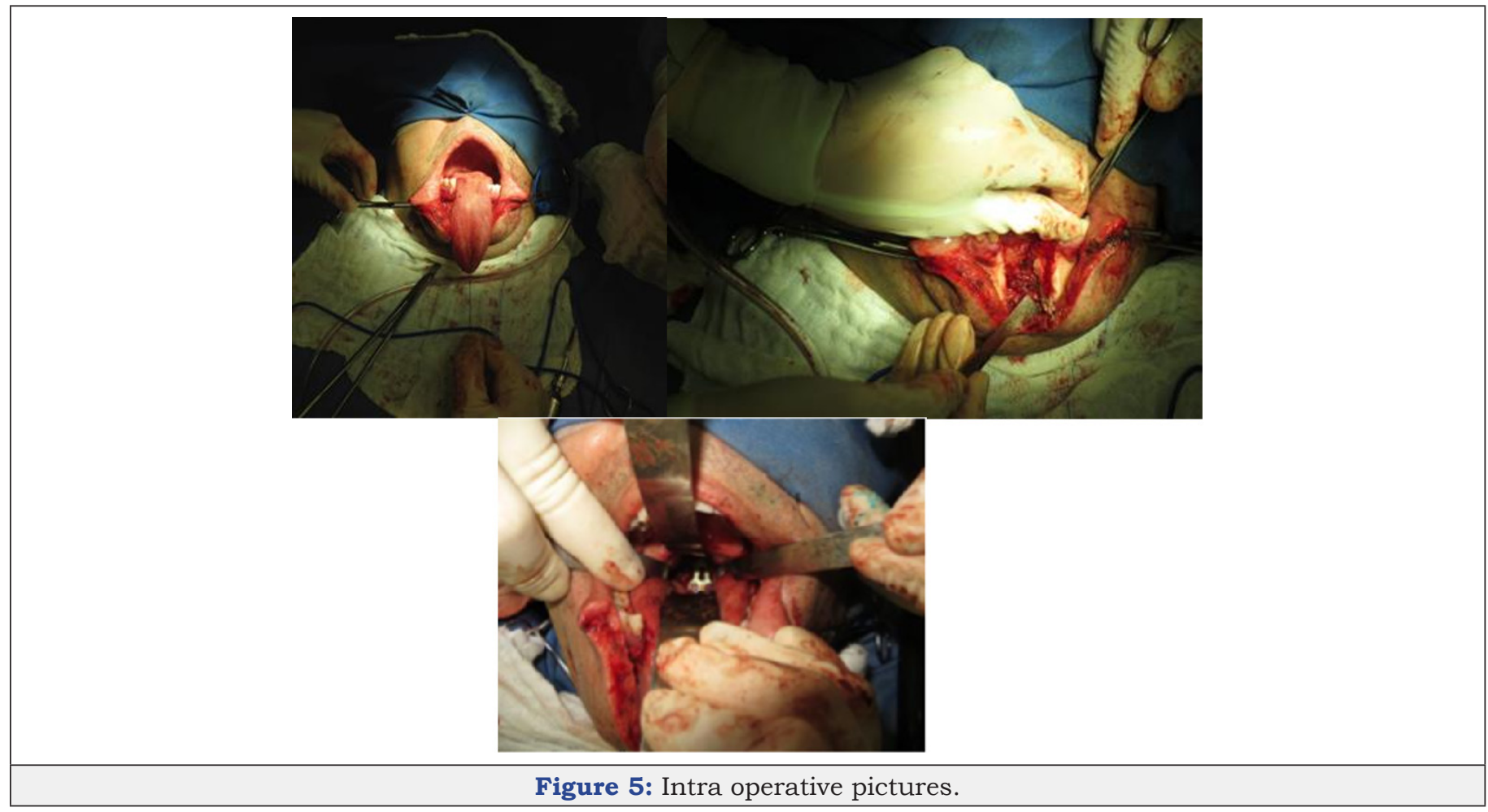




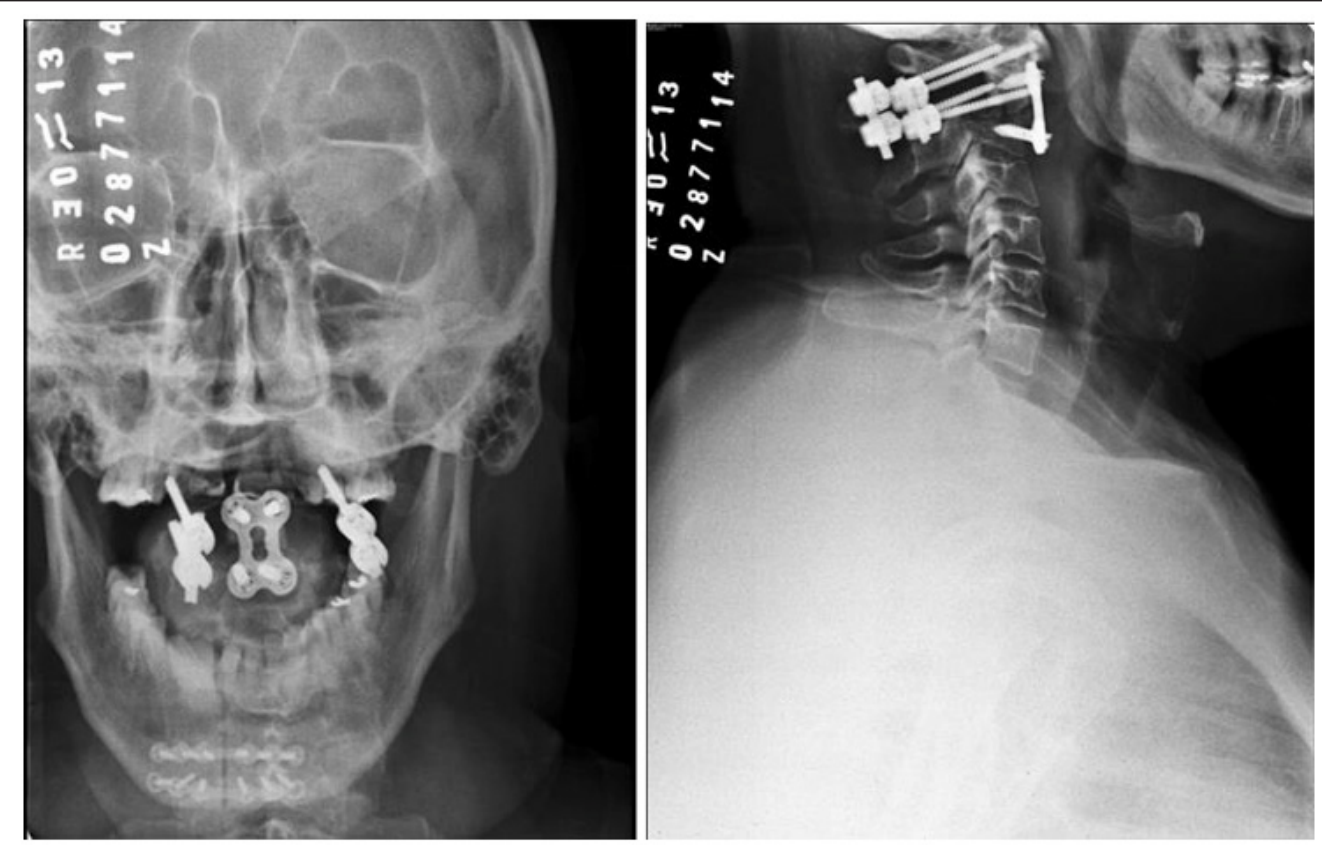

Figure 6: Final RX.

\section{Revision and Discussion}

Aneurysmal bone cysts of the spine are rare, presenting predilection for the lumbar spine [34-38] and raising great consideration regarding differential diagnoses. They are: osteoblastomas, osteosarcomas, osteoid osteomas, giant cell tumors, aneurysmal bone cyst, osteochondromas, chondrosarcomas, chondromas and Ewing sarcoma [24].

Gidding et al. point out the history of sub periosteal trauma with an incorrect and exaggerated repair, with the presence of hemorrhage $[34,39]$. In the case described herein, the patient did not report any remote traumas in his vertebral spine. We thus resorted to the hypotheses of primary tumor of genetic or even vascular etiology.

We here present the case of an adult male with CII aneurysmal bone cyst, who checked in our service with a complaint of mechanical neck pain, hypersensitivity, besides limited cervical motion. X-ray photograph, despite being an in conclusive imaging exam for aneurysmal bone cysts [40], was requested, with typical findings, such as rare faction are as, well circumscribed lytic lesion, and the presence of thin trabeculae.

Some authors consider pre-surgery puncture biopsy dispensable, having image tests as the only basis. In this case, presurgery puncture biopsy in CII was performed, which allowed discarding other pathologies, making the diagnosis of aneurysmal bone cyst conclusive.

Treating aneurysmal bone cyst is challenging, and in the literature researched, although selective arterial embolization (SAE) is described as a first-choice treatment, there was a great trend for surgical treatment with complete resection of the lesion due to the success verified in multiple cases described. A number of authors consider curettage alone a high risk for relapses, considering the adjuvancy with Phenol or Ethanol [40-42].

In this case report, due to the locally aggressive behavior of the tumor, cervical spine instability, expansibility and neurological complications, we opted for surgical resection, grafting, stabilization and local infusion of corticoid. Similar cases are described in the literature journals, also at three surgical times, yet we identified changes in the order of the approaches. Other authors considered performing the biopsy followed by resection and cervical spine stabilization, whereas in our case, stabilization was performed at the second time with cervical arthrodesis of CI/CII and grafting. The resection of vertebral discs CII/CIII and of the Odontoid body was performed at a third time, with the association of plates and screws, after the patient's signs of myelopathy.

The control of the patient through CT was performed eight months after the last surgical intervention, with successful system stabilization. The objective was thus met, with the complete excision of the tumor, reduced risk of relapse and minimum morbidity.

\section{References}

1. Emanuel DOS, Ana CAG, Ronaldo de CR, Ricardo WFC,Thiago SS (2007) Aneurysmatic osseous cyst: A case report and literature review. Rev Cir Traumatol Buco-Maxilo-Fac 7(4): 9-18

2. Barbosa EF, Lima JA, Rocha FZ, Barbosa SM, Lima PMA (1998) Cisto ósseo aneurismático em costela: relato de caso. Rev Bras Ortop 33: 1001-1002.

3. Braun A, Helmich A (1988) Clinical introduction to aneurysmatic bone cysts. Z OrthopIhre Grenzgeb 126(4): 448-457.

4. Fernandes CD, Figueiredo AJA, Murta EFC, Barros JW (1996) Cisto ósseo aneurismático no sacro. Rev Bras Ortop 31: 181-183.

5. Oliveira CRGCM, Basile R, Camargo OP, Zerbini MCN, Lula DAAM, et al. (2006) The correlation between imaging tests, anatomopathological and immunohistochemical characteristics in an aggressive giant cell tumor of the bone, located in the spine. Acta Ortoped Bras 14: 170-172. 
6. Mehmet Z, Hasan SI, Fatih EO, Merih I, Sedat C, et al. (2013) Aneurysmal bone cysts of the spine. Eur Spine J 22(3): 593-601.

7. Vergel de DAM, Bond JR, Shives TC, McLeod RA, Unni KK (1992) Aneurysmal bone cyst. A clinicopathologicstudyof 238 cases. Cancer 69: 2921-2931.

8. Leithner A, Windhager R, Lang S, Haas O, Kainberger F, et al. (1999) Aneurysmal bone cyst. A population based epidemiologic study and literature review. Clin Orthop Relat Res 363: 176-179.

9. Pennekamp W, Peters S, Schinkel C, Kuhnen C, Nicolas V, et al. (2008) Aneurysmal bone cyst of the cervical spine. Eur Radiol 18: 2356-2360.

10. Al-Shamy G, Relyea K, Adesina A, Whitehead WE, Curry DJ, et al. (2011) Solid variant of aneurysmal bone cyst of the thoracic spine: a case report. J Med Case Rep 5(261): 1-6.

11. Assoun J, Richardi G, Bonevialle P, Poey C (1993) Osteoide osteoma: Percutaneous resection with CT guidance. Radiology 188(2): 541-547.

12. Goley JP (1986) A 10-year retrospection of the treatment of unicameral bone cyst. J Bone Joint Surg 68B: 675.

13. Jesus-Garcia R (1987) Novos conceitos em biópsia óssea. Rev Bras Ortop Traumat 22(6): 168.

14. Dahlin DC, Unni KK (1986) Bone tumors, ed 4a. Charles C (Edn.), Thomas Springfield, Illinois, USA.

15. Jessica AG, Kelly CW, Marcelo HF, Tiago EFC (2014) Cisto ósseo aneurismático em costela. Revista da AMRIGS 58(2): 135-139.

16. Seock YL, Seung JL, Cheol SL, Kihl RL (2008) Aneurysmal bone cyst originating from the first rib. The American Journal of Surgery 195(1): 104-105.

17. Novais EN, Rose PS, Yaszemski MJ, Sim FH (2011) Aneurysmal bone cyst of the cervical spine in children. J Bone Joint Surg Am 93: 1534.

18. Omami G, Mathew R, Gianoli D, Lurie A (2012) Enormous aneurysmal bone cyst of the mandible: case report and radiologic-pathologic correlation. Oral and Maxillofacial Radiology.

19. Liu X, Han SB, Si G (2018) Eur Spine J.

20. Dal CP, Kozakewich HP, Goumnerova L, Mankin HJ, Rosenberg AE, et al. (2000) Variant translocations involving 16q22 and 17p13 in solid variant and extraosseous forms of aneurysmal bone cyst. Genes Chromosomes Cancer 28: 233-234.

21. Shiels WE, Mayerson JL (2013) Percutaneous doxycycline treatment of aneurysmal bone cysts with low recurrence rate: a preliminary report. Clin Orthop Relat Res 471(8): 2675-2683.

22. Dormans JP, Hanna BG, Johnston DR, Khurana JS (2004) Surgical treatment and recurrence rate of aneurysmal bone cysts in children. Clin Orthop Relat Res 421: 205-211.

23. Hauschild O, Lüdemann M, Engelhardt $M$, Baumhoer D, Baumann $T$, et al. (2016) Aneurysmal bone cyst (ABC): treatment options and proposal of a follow-up regime. Acta Orthop Belg 82: 474-483.

24. Vale, Benjamim P, Alencar, Francisco J, Aguiar, et al. (2005) Cisto ósseo aneurismático vertebral: estudo de três casos. Arquivos de NeuroPsiquiatria 63(4): 1079-1083.
25. Ozaki T, Halm H, Hillmann A, Blasius S, Winkelmann W (1999) Aneurysmal bone cyst of the spine. Arch Orthop Trauma Surg 119: 159162.

26. Meyer S, Reinhard H, Graf N, Kramann B, Schneider G (2002) Arterial embolization of a secondary aneurysmatic bone cyst of the thoracic spine prior to surgical excision in a 15-year-old girl. Eur J Radiol 43: 7981.

27. Otsuka T, Kobayashi M, Sekiya I (2002) Treatment of an aneurismal bone cyst of the second matatarsal using an endoscopic approach. J Foot Ankle Surg 41: 238-242.

28. Leone A, Costantini A, Guglielmi G, Settecasi C, Priolo F (2000) Primary bone tumors and pseudotumors of the lumbosacral spine. Rays 25(1): 89-103.

29. Neva J, Smith BW, Joseph JR, Park P (2017) Use of intra operative navigation for reconstruction of the $\mathrm{C} 1$ lateral mass after resection of aneurysmal bone cyst. World Neurosurgery 102.

30. Bongioanni F, Assadurian E, Polivka M, George B (1996) Aneurysmal bone cyst of the atlas: operative removal through an anterolateral approach. A case report. J Bone Joint Surg Am 78(10): 1574-1577.

31. Wang VY, Deviren V, Ames CP (2009) Reconstruction of C-1 lateral mass with titanium mesh cage after resection of an aneurysmal bone cyst of the atlas. J Neurosurg Spine 10(2): 117-121.

32. Bandiera S, Ghermandi R, Gasbarrini A, Barbanti BG, Colangeli S, et al. (2013) Navigation-assisted surgery for tumors of the spine. Eur Spine J 22 Suppl 6: S919-924.

33. Hakim DN, Pelly T, Kulendran M, Caris JA (2015) Benign tumours of the bone: A review. J Bone Oncol 4(2): 37-41.

34. Alexandre BS, Antonio ATB, Kauê S, Daniel E, Norberto K, et al. (2006) Cisto ósseo aneurismático cervical. Rev Bras Cir Cabeça Pescoço 35(4): 267-270.

35. Cottalorda J, Kohler R, Sales de GJ (2004) Epidemiology of aneurysmal bone cyst in children: a multicenter study and literature review. J Pediatr Orthop B 13(6): 389-394.

36. Volikas Z, Singounas E, Saridakes G (1982) Aneurysmal bone cyst of the spine. Report of a case. Acta Radiol Diagn (Stockh) 23(6): 643-646.

37. Gailloud P, Martin JB, Olivi A (2002) Transoral vertebroplasty for a fractured C2 aneurysmal bone cyst. J VascInterv Radiol 13(3): 340-341.

38. Garg S, Mehta S, Dormans JP (2005) Modern surgical treatment of primary aneurysmal bone cyst of the spine in children and adolescents. J Pediatr Orthop 25(3): 387-392.

39. Stillwell WT, Fielding JW (1984) Aneurysmal bone cyst of the cervicodorsal spine. c (187): 144-146.

40. Adriano JF, Sebastião AL, Murilo AR, Valdênia das GN, Giovanni BPL, Antonio COM (2016) Solid variant of aneurysmal bone cist on the distal extremity of the radius in a child. Revista Brasileira de Ortopedia (English Edition) 51(3): 370-373.

41. Bertoni F, Bacchini P, Capanna R, Ruggieri P, Biagini R, et al. (1993) Solid variant of aneurysmal bone cyst. Cancer 71(3): 729-734.

42. Mankin HJ, Hornicek FJ, Ortiz-Cruz E, Villafuerte J (2005) Aneurysmal bone cyst: a review of 150 patients. J Clin Oncol 23(27): 6756-6762. 